\title{
Endophytic Actinobacteria Induce Defense Pathways in Arabidopsis thaliana
}

\author{
V. M. Conn, ${ }^{1}$ A. R. Walker, ${ }^{2}$ and C. M. M. Franco ${ }^{1}$ \\ ${ }^{1}$ Department of Medical Biotechnology, Flinders University, Bedford Park, South Australia 5042, Australia; ${ }^{2} \mathrm{CSIRO}$ Plant \\ Industry, PO Box 350, Glen Osmond, Adelaide 5064, Australia
}

Submitted 22 May 2007. Accepted 23 October 2007.

Endophytic actinobacteria, isolated from healthy wheat tissue, which are capable of suppressing a number wheat fungal pathogens both in vitro and in planta, were investigated for the ability to activate key genes in the systemic acquired resistance $(\mathrm{SAR})$ or the jasmonate/ethylene (JA/ET) pathways in Arabidopsis thaliana. Inoculation of $A$. thaliana (Col-0) with selected endophytic strains induced a low level of SAR and JA/ET gene expression, measured using quantitative polymerase chain reaction. Upon pathogen challenge, endophyte-treated plants demonstrated a higher abundance of defense gene expression compared with the non-endophyte-treated controls. Resistance to the bacterial pathogen Erwinia carotovora subsp. carotovora required the JA/ET pathway. On the other hand, resistance to the fungal pathogen Fusarium oxysporum involved primarily the SAR pathway. The endophytic actinobacteria appear to be able to "prime" both the SAR and JA/ET pathways, upregulating genes in either pathway depending on the infecting pathogen. Culture filtrates of the endophytic actinobacteria were investigated for the ability to also activate defense pathways. The culture filtrate of Micromonospora sp. strain EN43 grown in a minimal medium resulted in the induction of the SAR pathway; however, when grown in a complex medium, the JA/ET pathway was activated. Further analysis using Streptomyces sp. strain EN27 and defense-compromised mutants of $A$. thaliana indicated that resistance to $E$. carotovora subsp. carotovora occurred via an NPR1-independent pathway and required salicylic acid whereas the JA/ET signaling molecules were not essential. In contrast, resistance to $F$. oxysporum mediated by Streptomyces sp. strain EN27 occurred via an NPR1-dependent pathway but also required salicylic acid and was JA/ET independent.

Plants have developed a nonspecific mechanism of defense that can provide long-term protection against a broad number of pathogens. Systemic acquired resistance (SAR) is induced by prior inoculation with a necrotizing pathogen or the application of chemical agents such as salicylic acid (SA), 2-6-dichloro isonicotinic acid (INA), and benzo $(1,2,3)$ thiadiazole7-carbothioic acid $S$-methyl ester (BTH) (Uknes et al. 1992). Once activated, the SAR pathway can confer resistance to a number of pathogens. SAR has been studied extensively in the dicots, tobacco (Nicotiana tabacum), and Arabidopsis thaliana

Corresponding author: Chris Franco; Telephone: +61 88204 5764; Fax: +61 88204 4101; E-mail: Chris.Franco@flinders.edu.au

Current address of V. Conn: Australian Centre for Plant Functional Genomics, PMB1, Glen Osmond, Adelaide 5064, Australia. and is characterized by an early increase of endogenously synthesized SA and the enhanced production of pathogenesisrelated (PR) proteins, specifically PR-1, PR-2, and PR-5 (Uknes et al. 1992). It has been suggested that a mobile signal is produced and thought to move from the site of attack via the phloem to the rest of the plant establishing systemic resistance (Maldonado et al. 2002).

In addition to the SAR pathway, the jasmonic acid/ethylene (JA/ET) pathway functions in an SA-independent manner and results in the production of antimicrobial compounds that confer resistance to a number of pathogens. JA are important plantsignaling molecules involved in a variety of critical functions, including fruit ripening, senescence, tuber formation, tendril coiling, pollen formation, and defense response against pests and pathogens (Creelman and Mullet 1997). In Arabidopsis, JA inhibit root elongation and are required for pollen development and pathogen defense (Ellis and Turner 2001). Like JA, ET $\left(\mathrm{C}_{2} \mathrm{H}_{4}\right)$ is an important plant-signaling molecule involved in many plant functions, including seed germination, root hair development, root nodulation, flower senescence, abscission, and fruit ripening (Wang et al. 2002). Application of ET, or its precursor, 1-aminocyclopropane-1-carboxylic acid (ACC), has been shown to trigger a pathway leading to the upregulation of the defense genes PDF1.2 and Hel. ET production is increased upon exposure to abiotic and biotic stresses, including extreme temperatures, drought, anaerobic conditions, wounding, herbivory, and infection by viral, bacterial, and fungal pathogens (Abeles et al. 1992). JA and ET both are implicated in the activation of genes encoding plant defensins and enzymes involved in phytoalexin biosynthesis (Pieterse et al. 1998). The JA and ET signaling leads to the induction of the PR proteins: PR-3, a basic chitinase; PR-4, a chitin-binding protein; and PDF1.2. PDF1.2 is a member of the group of plant defensins, which is a family of peptides with antimicrobial activities and includes the thionins, lipid transfer proteins, hevein-type, knottin-type, and anti-microbial peptides (van Loon and van Stein 1999). In Arabidopsis, the JA/ET pathway induces resistance to the fungal pathogens Alternaria brassicicola, Botrytis cinerea, and Fusarium oxysporum f. sp. matthiolae (van Loon and van Stein 1999).

Nonpathogenic rhizobacteria have been shown to induce resistance in plants that is phenotypically similar to SAR. This has been termed induced systemic resistance (ISR) and it is believed that the pathway is distinct from the SAR pathway but is mediated by a JA/ET pathway (Hammerschmidt 1999; Pieterse et al. 2002; van Wees et al. 1999). Pieterse and associates (1998) investigated ISR in Arabidopsis, using as the inducing agent the nonpathogenic, root-colonizing Pseudomonas fluorescens WCS417r, which triggers ISR in carnation (van Peer et al. 1991), radish (Leeman et al. 1995), tomato (Duijff et al. 1996), 
and Arabidopsis (Pieterse et al. 1996). P. fluorescens WCS417r ISR is independent of SA accumulation and $P R$ gene activation in Arabidopsis and, through investigation of mutants, it was concluded that the mechanisms involved in ISR could be different from those in the SAR and JA/ET pathways (Pieterse et al. 1998). P. fluorescens WCS417r confers resistance to $F$. oxysporum f. sp. raphani, the oomycetous leaf pathogen Peronospora parasitica, and the bacterial leaf pathogens Xanthomonas campetris pv. campetris and Pseudomonas syringae pv. tomato, indicating that ISR is effective against different types of pathogens (van Wees et al. 2000). Conrath and associates (2002) suggested that the nonpathogenic bacteria prime the plant for accelerated and enhanced response to a second stress stimulus, such as a pathogen. This theory was further enhanced by Verhagen and associates (2004), whose microarray analysis was used to identify ISR-related genes in Arabidopsis. More than 8,000 genes were surveyed and it was found, when using the ISRinducing bacterium $P$. fluorescens WCS417r, that, although there was a substantial change in the expression of 97 genes in the roots, no changes in expression of any genes could be detected in the leaves. However, after subsequent challenge with $P$. syringae pv. tomato DC3000, there was a change in the expression of 81 genes in the leaves, indicating the role of rhizobacteria in priming the plant for ISR.

Endophytic actinobacteria isolated from healthy wheat plants have been shown to enhance disease resistance in wheat when applied as a seed coating. Actinobacteria are recognized as metabolically and morphologically more complex than sessile bacteria. Metabolically, they are prolific producers of an array of secondary metabolites, including antimicrobial agents, plant growth hormones, and siderophores. Morphologically, they produce mycelia and spore structures which will result in a different mode of plant colonization compared with sessile bacteria. These activities can be harnessed by employing endophytic actinobacteria for biocontrol and plant growth promotion. Inoculation of wheat with the endophytic actinobacterium, Streptomyces sp. strain EN27, has been shown to promote growth and enhance disease resistance both in vitro and in planta (Coombs 2002). Coombs and associates (2003) further demonstrated that, in steam-sterilized as well as field soils inoculated with Gaeumannomyces graminis var. tritici, the causative agent of "take-all," there was a significant disease reduction in Streptomyces sp. strain EN27-treated wheat plants compared with untreated controls. Actinobacteria are prolific producers of antibiotics which may account for the disease resistance, though it is possible the endophytes are capable of activating a systemic defense response similar to the ISR mediated by rhizobacteria.

The aim of this study was to determine the mechanism by which selected endophytic actinobacteria enhance disease resistance, using Arabidopsis as a model plant because its defense pathways have been studied extensively. Quantitative polymerase chain reaction (QPCR) was used to determine the level of gene induction in the SAR (PR-1 and $P R-5)$ and JA/ET (PDFl.2 and $\mathrm{Hel}$ ) pathways of Arabidopsis as a result of endophytic actinobacteria inoculation. The defense response that was recorded via both pathways was dissected further by employing the defense-compromised mutants NahG (SA de- grading), nprl-1 (nonexpression of PR proteins), etrl-3 (ET insensitive), and jarl-1 (JA insensitive).

\section{RESULTS}

\section{Induction of gene expression}

in the SAR and JA/ET pathways using chemical elicitors.

The QPCR first was validated by quantifying the induction of the SAR genes, $P R-1$ and $P R-5$, and the JA/ET genes, PDF 1.2 and $\mathrm{Hel}$, by the application of the chemical elicitors SA, methyl jasmonate (MeJA), and ACC onto 6- to 8-week-old Arabidopsis plants. The application of SA to the Arabidopsis plant previously has been shown to trigger the SAR pathway and, as a result, the $P R-1$ and $P R-5$ transcripts are increased (Uknes et al. 1992) (Table 1). These genes were not induced by MeJA or ACC. As expected, the application JA and ET stimulated the upregulation of the PR genes $\mathrm{Hel}$ and PDF1.2 (van Loon and van Stein 1999). The application of SA also induced the $\mathrm{Hel}$ transcript, but to a lower extent.

\section{The effect of endophytic actinobacteria} on key genes in the SAR and JA/ET pathways.

Inoculation of the Arabidopsis seed with actinobacteria endophytes was performed to determine whether induction of genes in the SAR and JA/ET pathways occurred in mature plants. Plants were harvested after approximately 7 weeks of growth and the changes in gene expression analyzed by QPCR (Fig. 1). The actinobacteria endophytes are nonpathogenic and all plants appeared healthy at the time of harvest. Though the endophytic actinobacteria used in this study have been isolated from wheat plants, they have a wide host range and have mediated growth promotion in Arabidopsis. Inoculation of Arabidopsis seed with Streptomyces sp. strain EN27 resulted in a

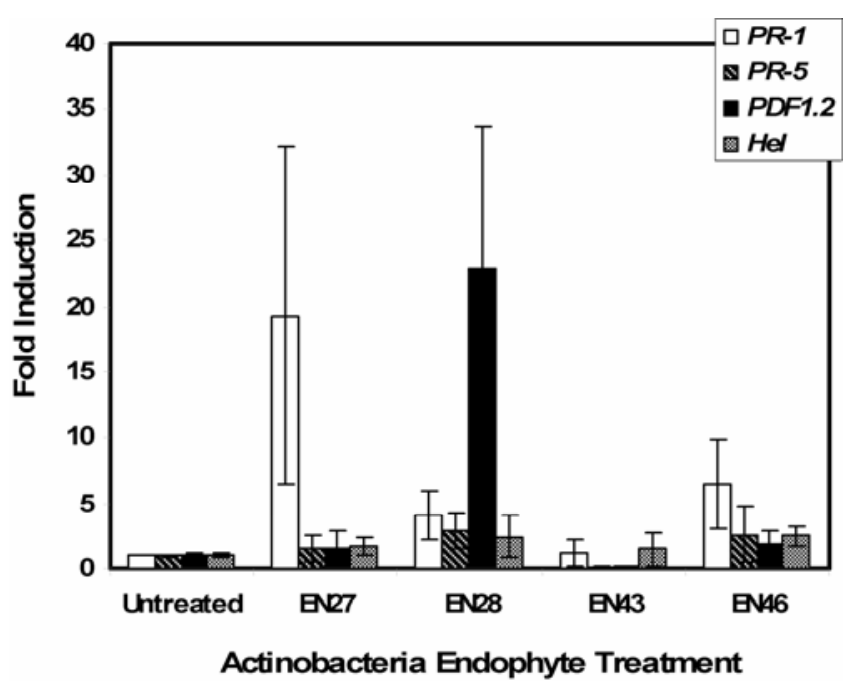

Fig. 1. Fold induction of the $P R-1, P R-5, P D F 1.2$, and $\mathrm{Hel}$ transcripts in 7week-old Arabidopsis thaliana (Col-0) plants preinoculated with the endophytic actinobacteria Streptomyces sp. strain EN27, Streptomyces sp. strain EN28, Micromonospora sp. strain EN43, and Nocardioides albus EN46, compared with untreated plants.

Table 1. Fold induction of the $P R-1, P R-5, P D F 1.2$, and $\mathrm{Hel}$ transcripts after treatment with salicylic acid (SA), methyl jasmonate (MeJA), and 1aminocyclopropane-1-carboxylic acid (ACC) and normalized against actin

\begin{tabular}{lccccc}
\hline Treatment & Time after treatment (h) & PR-1 & PR-5 & Hel & PDF1.2 \\
\hline SA & 6 & $1,682 \pm 876$ & $3.9 \pm 1.4$ & $1.6 \pm 1.0$ & $1.0 \pm 0.2$ \\
SA & 24 & $1,468 \pm 508$ & $1.1 \pm 0.1$ & $4.5 \pm 0.2$ & $1.2 \pm 0.03$ \\
ACC & 24 & $2.0 \pm 0.57$ & $0.5 \pm 0.15$ & $6.1 \pm 2.26$ & $11.1 \pm 1.19$ \\
MeJA & 24 & $1.4 \pm 1.93$ & $0.3 \pm 0.07$ & $8.3 \pm 0.41$ & $69.1 \pm 3.5$ \\
\hline
\end{tabular}


19-fold induction of the $P R-1$ transcript in 7-week-old plants, whereas the closely related strain, Streptomyces sp. strain EN28, was able to induce $P R-1, P R-5$, and $P D F 1.2$ by $4-, 3-$, and 23-fold, respectively, compared with the uninoculated control. Inoculation with Nocardioides albus EN46 resulted in induction of $P R-1$ and PR-5. Micromonospora sp. strain EN43 had no effect on $P R-1$ and $\mathrm{Hel}$, but suppressed the expression of $P R-5$ and PDF1.2 compared with control plants.

The effect of Erwinia carotovora subsp. carotovora on the induction of SAR and JA/ET pathways genes following inoculation with endophytic actinobacteria.

Arabidopsis (Col-0) plants grown from endophytic actinobacteria-inoculated seed and untreated controls were challenged with the bacterial pathogen Erwinia carotovora subsp. carotovora after approximately 7 weeks of growth. Three days after infection, the untreated plants showed severe disease symptoms of soft rot and, by day 5 , were completely necrotic and had collapsed, whereas all the endophyte-treated plants showed a normal appearance (Fig. 2) and stayed healthy beyond 6 days after pathogen infection.

Analysis of gene expression (Fig. 3) in the untreated (diseased) plants infected with E. carotovora subsp. carotovora showed that the JA/ET pathway was strongly upregulated, because PDF1.2 demonstrated the largest induction of gene expression. In all the endophytic actinobacteria-treated (healthy) plants, the PDF1.2 transcript was induced after the challenge with the Erwinia sp., with highest induction present in the $M i$ cromonospora sp. strain EN43- and N. albus EN46-treated plants. Of the endophyte-treated plants, only the Micromonospora EN43-treated plants demonstrated an induction of the $\mathrm{Hel}$ gene at levels above those shown in the untreated control plants.

The $P R-1$ transcript was not induced above the level of the non-endophyte-treated infected plant in the Streptomyces sp. strain EN27-, EN28-, and N. albus EN46-treated infected plants; whereas, in the Micromonospora sp. strain EN43-treated plants, $P R-1$ was induced at levels 17 times higher than the untreated control plants. The $P R-5$ gene was induced at a low level in both untreated and endophyte-treated infected plants.

The effect of $\boldsymbol{F}$. oxysporum on the induction of genes in the SAR and JA/ET pathways after pre-inoculation with endophytic actinobacteria.

Seven-week-old Arabidopsis (Col-0) plants grown from endophyte-inoculated seed were challenged with the fungal pathogen $F$. oxysporum. Three days after this challenge, the non-endophyte-treated plants showed symptoms of disease (yellowing leaves) which could not be seen in any of the endophyte-treated plants (data not shown). Infection of Arabidopsis with $F$. oxysporum resulted in the induction of genes (Fig. 3 ) in both the SAR and JA/ET pathways to some degree. The $P R-1$ and $P R-5$ transcripts were further induced in the endophytetreated infected plants, with the highest level of gene expression change detected in the Streptomyces sp. strain EN28treated plants, with an increase of 47.5 times and 12.7 times for the $P R-1$ and $P R-5$ genes, respectively, compared with the untreated infected plants. The $P D F 1.2$ transcript was induced in the Streptomyces sp. strain EN27-treated infected plants 2.5 times and the $\mathrm{Hel}$ transcript 2.1 times higher in the Streptomyces sp. strain EN28-treated infected plants compared with expression in the untreated infected plants.

The roots and leaves of Arabidopsis plants treated with Streptomyces sp. strain EN27 and infected with $F$. oxysporum were separated and the gene expression analyzed independently in the roots and leaves (data not shown). The $P R-1$ and $P D F 1.2$ transcripts could be detected only in the leaves, with an 850- and 84-fold induction, respectively, compared with the unprimed, uninoculated control plants. The $P R-5$ and Hel transcripts were induced in both the roots and leaves, four- and ninefold, respectively. This indicated that the changes in gene expression by the endophytes were indeed systemic, and appear to correlate with the resistant phenotype.

\section{The effect of endophytic actinobacterial culture filtrates on defense gene expression.}

Actinobacterial culture filtrates were used to treat Arabidopsis (Col-0) plants and the changes in gene expression were analyzed by QPCR (Fig. 4). Two different media were used to culture the actinobacteria: a minimal (FL026) and a complex (FL031) medium. The application of the culture filtrates from the Streptomyces sp. strains EN27 and EN28 cultures did not result in any significant gene induction compared with untreated control plants. When the FL026 culture filtrate of Micromonospora sp. strain EN43 was applied, the $P R-1$ and $P R-5$ transcripts were induced 9- and 16-fold, respectively, indicating activation of the SAR pathway. However, when the culture filtrate of the same strain grown in the complex medium FL031 was applied, the JA/ET pathway was more strongly induced: the PDF1.2 transcript 24-fold and the Hel transcript 8-fold. The metabolites of $N$. albus
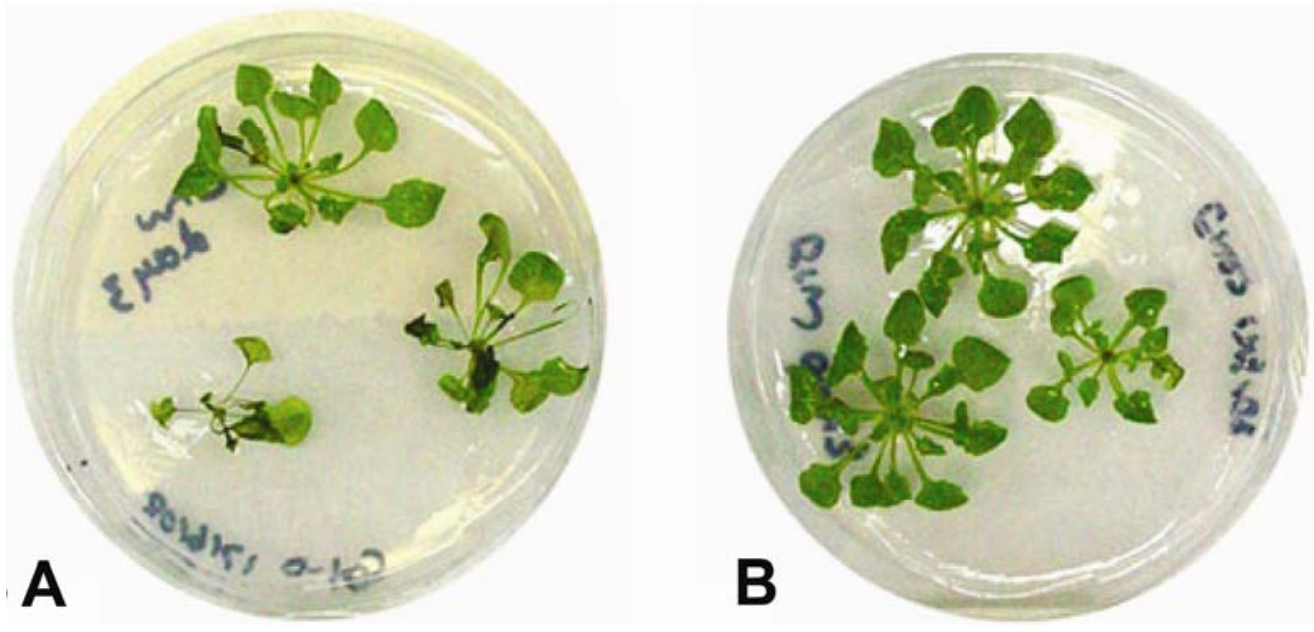

Fig. 2. Wild-type Arabidopsis thaliana Col-O infected with Erwinia carotovora subsp. carotovora. A, Wild-type Arabidopsis 3 days after inoculation with E. carotovora subsp. carotovora at $3 \times 10^{8} \mathrm{CFU} \mathrm{ml}^{-1}$. B, Wild-type Arabidopsis preinoculated with Streptomyces sp. strain EN27 at $1 \times 10^{8} \mathrm{CFU} \mathrm{ml}{ }^{-1} 3$ days after inoculation with $E$. carotovora subsp. carotovora at $3 \times 10^{8} \mathrm{CFU} \mathrm{ml}^{-1}$. 
EN46 induced the PDF1.2 transcript eightfold only when cultured in the complex medium.

Expression of defense genes in Streptomyces sp. strain EN27inoculated defense-compromised mutants

after challenge with $\boldsymbol{E}$. carotovora subsp. carotovora.

Defense-compromised mutants of Arabidopsis were employed to determine the role of the specific defense pathways involved in actinobacterial endophyte-mediated systemic defense. Inoculation of the SA-degrading lines of Arabidopsis, $N a h G$, with E. carotovora subsp. carotovora resulted in severe disease symptoms within the first $24 \mathrm{~h}$ and, by day three, the plants had started to collapse (Fig. 5A); all plants collapsed completely after 5 days. There was no enhanced disease resistance in the Streptomyces sp. strain EN27-inoculated NahG plants, whereas the Col-0 plants treated with Streptomyces sp. strain EN27 showed enhanced resistance (Fig. 2), with endophyte-treated plants remaining disease free and healthy after 6 days of pathogen treatment. No significant level of defense gene induction could be detected in the Streptomyces sp. strain EN27-inoculated infected $N a h G$ plant (data not shown). In the untreated infected $N a h G$, there was a low level of $P R-1$ induction but no $P R-5$ transcript could be detected. However, there was a significant induction of PDF1.2 and $\mathrm{Hel}$ (data not shown).

The nprl-1 mutant is compromised in $P R$ gene expression and application of $5 \mathrm{mM}$ SA was not able to induce $P R-1$ or $P R$ 5 gene expression (data not shown). Inoculation of the nprl-1 with $E$. carotovora subsp. carotovora resulted in disease symptoms comparable with infection in the Col-0 plant, whereas the Streptomyces sp. strain EN27-inoculated mutant plants demonstrated an enhanced resistance, though not to the extent seen in the wild-type plant (Fig. 5B). Comparative QPCR analysis revealed that the Streptomyces sp. strain EN27-treated npr1-1 plants had a decreased level of $P R-1$ transcript compared with the untreated infected nprl-1 plant (Fig. 6A), and that the JA/ET pathway genes were induced more strongly.

Application of the chemical elicitors MeJA and ACC to the jarl-1 and etrl-3 mutants confirmed that they were defective in their perception to JA and ET, respectively (data not shown). Inoculation of the jarl-1 and etrl-3 plants with E. carotovora subsp. carotovora resulted in disease symptoms comparable with infection in the wild-type plants. However, when seed were treated with Streptomyces EN27, the jar1-1 and etr1-3 plants showed enhanced resistance (Fig. 5C and D). The JA/ET pathway genes were significantly induced in the jar 1-1 and etr 1-3 mutants after challenge with the Erwinia sp., with a stronger induction of the PDF1.2 transcript than the Hel transcript (Fig. 6A).

Even though the Streptomyces sp. strain EN27-treated JA and ET mutant plants were resistant to Erwinia infection, the level of gene expression of PDF1.2 and $\mathrm{Hel}$ was lower than in the primed jarl-1 and etr1-3 mutants, though PRI generally was higher.

Expression of defense genes in Streptomyces sp. strain EN27inoculated defense-compromised mutants after challenge with $F$. oxysporum.

F. oxysporum infection of NahG and the nprl-1 mutant resulted in little expression of defense genes in both the SAR and JA/ET pathways and disease symptoms appeared earlier than in the infected wild type (Col-0). The same result was observed in EN27-treated mutants infected with $F$. oxysporum. QPCR revealed minimal expression of the $P R-1$ and $P R-5$ transcripts in both the uninfected untreated and endophytetreated NahG and nprl-1 mutants compared with infected Col-0 (Fig. 6B).
F. oxysporum infection of the jarl-1 and etrl-3 plants resulted in a considerably different gene expression profile compared with the SAR mutants (Fig. 6B). Most noticeably, the PR-1 transcript was significantly induced in the jarl-1 and etrl-3 mutants (380- and 468-fold, respectively) and was further enhanced in the Streptomyces sp. strain EN27-treated plants (1,188- and 663-fold, respectively). The PDF1.2 and Hel transcripts were significantly induced in the untreated jarl-1 and etrl-3 plants; however, this level of induction was reduced when the plants were inoculated with Streptomyces sp. strain EN27.

\section{DISCUSSION}

Nonpathogenic rhizobacteria have been shown to enhance disease resistance by stimulating the systemic defense pathways (Hammerschmidt 1999). In this study, inoculation of Arabidopsis with selected endophytic actinobacteria also was found to stimulate the plant defense pathways, though the elicitation profile of the genes involved was different from that previously
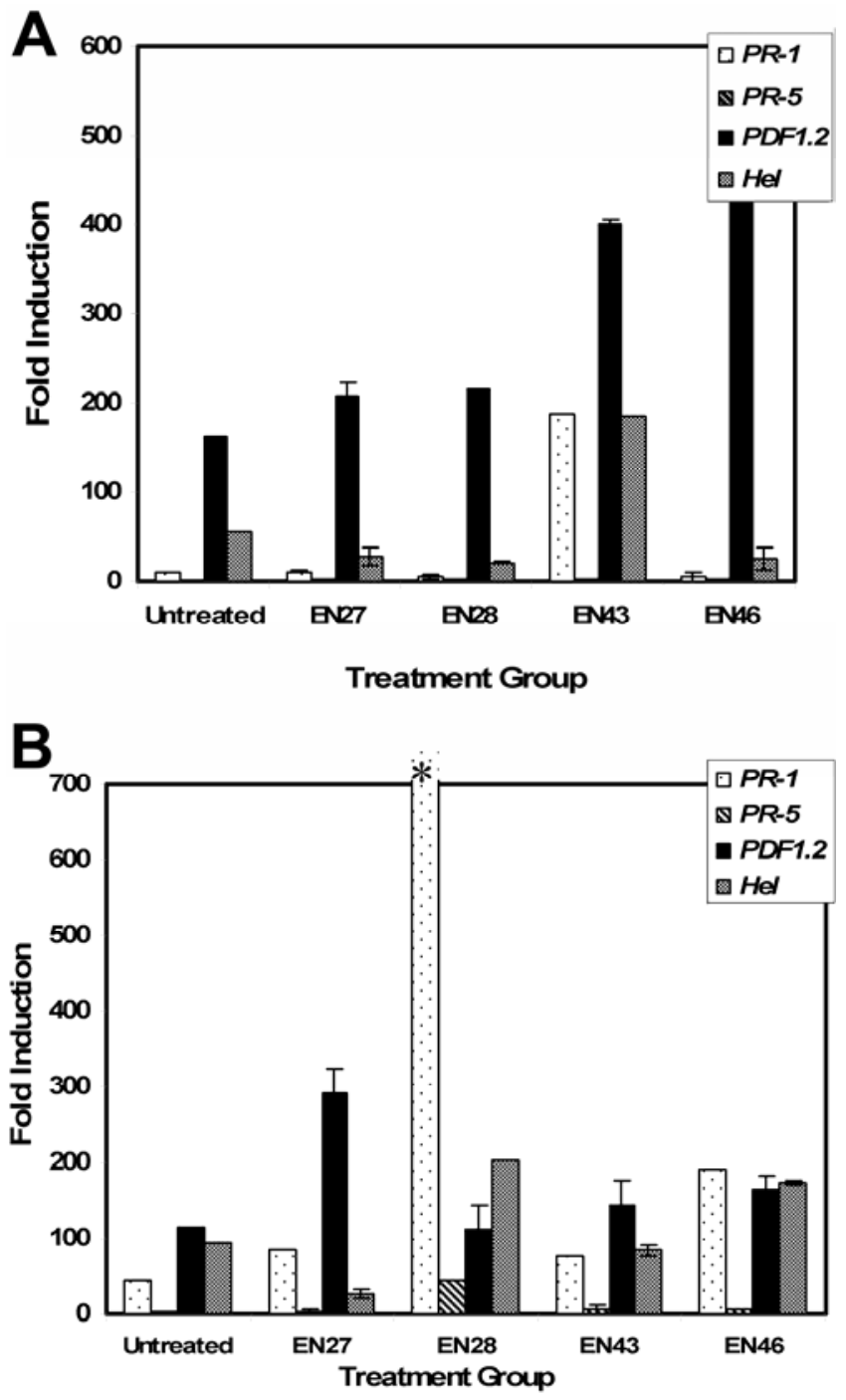

Fig. 3. Fold induction of the $P R-1, P R-5, P D F 1.2$, and $\mathrm{Hel}$ transcripts in 7 week-old Arabidopsis thaliana (Col-0) plants preinoculated with the endophytic actinobacteria Streptomyces sp. strains EN27 and EN28, Micromonospora sp. strain EN43, and Nocardioides albus EN46 and 3 days postchallenge with A, Erwinia carotovora subsp. carotovora and B, Fusarium oxysporum, compared with untreated plants; * represents a fold induction of 2,138 . 
reported using other plant-growth-promoting bacteria or biocontrol bacterial strains. The SAR pathway in Arabidopsis normally is activated by biotrophic pathogens either as a part of the hypersensitive response or as a symptom of disease and the JA/ET pathway is triggered by infection with necrotrophic pathogens (Dong and Durrant 2004; Glazebrook 2005; Thaler et al. 2004). Inoculation with Streptomyces sp. strain EN27 resulted in activation of the SAR pathway via induction of the PR-1 gene, whereas Streptomyces sp. strain EN28 primarily triggered the JA/ET pathway because the $P D F 1.2$ gene was expressed to a higher degree than the $P R-1$ and $P R-5$ transcripts. The Streptomyces sp. strains EN27 and EN28 are highly similar to each other morphologically and by $16 \mathrm{~S}$ rRNA gene sequence homology; however, it is well known that different strains of the same actinobacterial species can produce a different range of secondary metabolites (Hopwood 2003). The N. albus EN46 strain appeared to activate the SAR pathway, whereas the Micromonospora sp. strain EN43 was unable to upregulate the plant defense genes examined. In contrast to the Streptomyces and Nocardioides strains, the well-studied nonpathogenic rhizobacteria $P$. fluorescens WCS417r (van Wees et al. 1999) and P. fluorescens LSW17S (Ahn et al. 2007) do not induce SA- or JA-responsive genes by inoculation with the rhizobacterium alone. The selected endophytic actinobacteria used in this study activated the plant defense genes in the absence of a pathogen, suggesting that the actinobacteria are detected as "minor" pathogens which do not trigger a full resistance response on their own, because they do not have pathogenic determinants, and this may result in more effective priming of the defense response, as was seen in this study.

Systemic induction of the SAR and JA/ET genes is thought to occur via a lipid-derived signal that can be transported through the phloem (Maldonado et al. 2002). Because actinobacteria are prolific producers of secondary metabolites, including antifungal agents (Nolan and Cross 1988), it was necessary to determine whether the elicitation of the defense pathways could be mediated by a secreted secondary metabolite or excreted cell factor. Induction of SAR and JA/ET genes was detected only with the Micromonospora sp. strain EN43 and N. albus EN46 culture filtrates. Interestingly, the culture filtrate of EN43 grown in a minimal medium resulted in the induction of the SAR pathway but, when grown in a complex medium, the JA/ET pathway was activated. This suggests that a different suite of (secondary) metabolites produced in each medium is responsible for the activation of the defense pathways.

Previously, it was shown by Ryu and associates (2004) that volatile organic compounds from Bacillus subtilis GB03 and B. amyloliquefaciens IN937a were able to induce ISR in Arabidopsis and reduce the disease severity of E. carotovora subsp. carotovora. Isolating the actinobacteria endophyte compound or compounds responsible for the activation of the defense genes could lead to the identification of a biochemical biological control agent. However, it may be possible that the physical interaction of the endophyte and host plant is needed for the full range of defense responses to be activated.

The priming response was displayed in Arabidopsis plants inoculated with endophytic actinobacteria at planting when challenged after 7 weeks with pathogens. Infection of Arabidopsis with the nonspecific bacterial plant pathogen E. carotovora subsp. carotovora, which causes soft-rot disease in a wide range of hosts (Aguilar et al. 2002; Norman et al. 1999), has been shown to induce the local and systemic expression of genes that are mainly responsive to ET or JA (e.g., $\mathrm{Hel}$, ChiB, PDF 1.2, and Atvsp) (Norman-Setterblad et al. 2000). It was confirmed in this study by QPCR that strong induction of the PDF1.2 and Hel transcripts occurred in the Col-0 plants infected with this pathogen. Inoculation with all four actinobacteria endophytes resulted in an enhanced level of resistance because the plants appeared healthy 3 days after challenge compared with the untreated plants, which exhibited disease symptoms. This resistance correlated with induction of PDF1.2 transcript above the level detected in the untreated infected control. $M i$ cromonospora sp. strain EN43 was the only endophyte that did not induce the SAR or JA/ET pathway genes in the absence of a pathogen; however, it also carried the capacity to prime the SAR and JA/ET pathways, enabling a stronger defense response upon pathogen invasion, which correlated with a resistant phenotype. In this regard, Micromonospora sp. strain EN43 appears

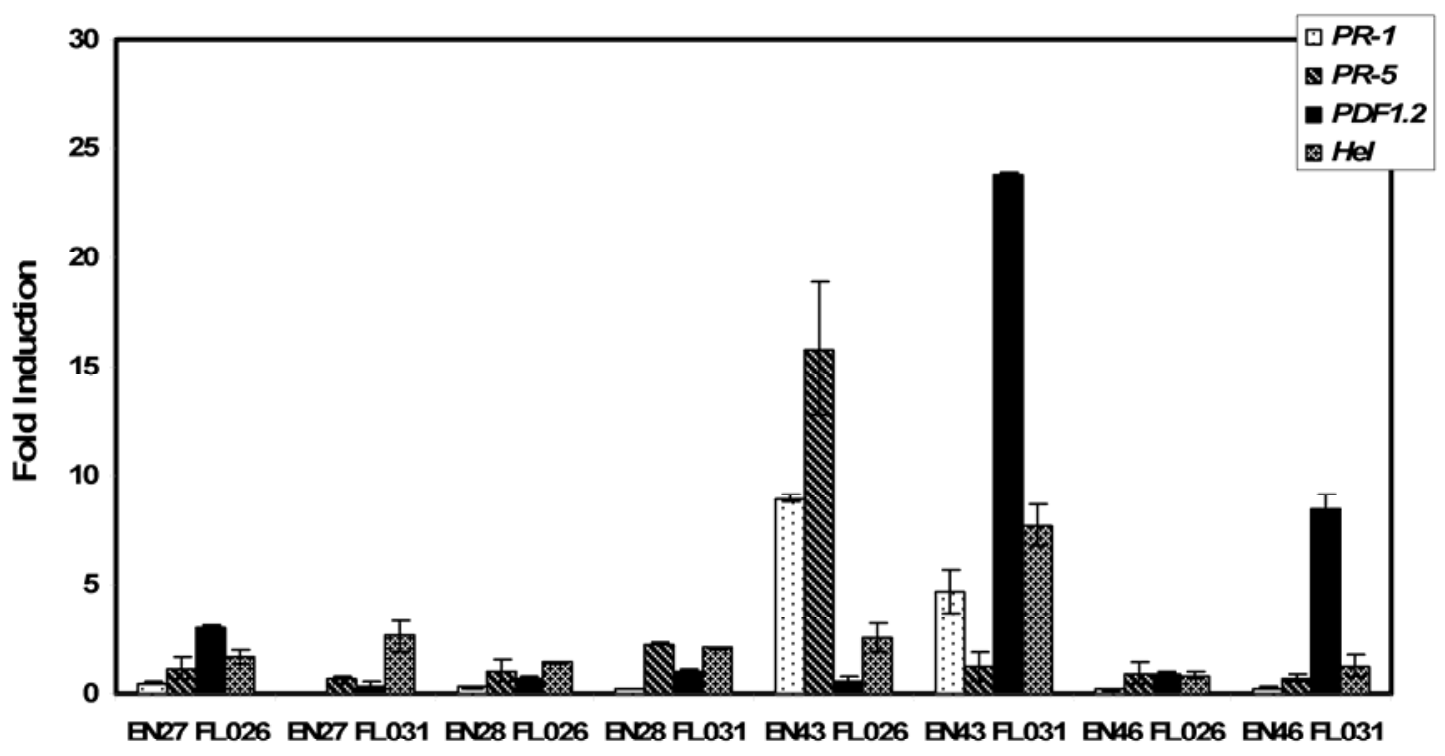

Actinobacteria Endophyte Culture Filtrates

Fig. 4. Effect of culture filtrates of actinobacteria endophytes Streptomyces sp. strain EN27 and EN28, Micromonospora sp. strain EN43, and Nocardioides albus EN46, grown in two different media, FL026 and FL031, on genes in the systemic acquired resistance and jasmonic acid/ethylene pathways in 7-weekold Arabidopsis thaliana (Col-0), $24 \mathrm{~h}$ posttreatment. 
to be able to induce resistance in a manner similar to $P$. fluorescens WC417r or LSW17S, where the treatment with these nonpathogenic root-colonizing bacteria alone do not elicit a detectable defense response. However, upon challenge with a pathogen such as $P$. syringae pv. tomato DC3000, the $P$. fluorescens WC417r-treated plants displayed a potentiated defense response compared with that detected by pathogen alone. It was concluded that $P$. fluorescens $\mathrm{WC} 417 \mathrm{r}$ was priming the plant defense pathways-where inoculation with this bacterium alone does not induce the plant defense response but, when attacked by a pathogen, the defense response is mounted quickly, inducing systemic resistance (Conrath et al. 2002; Verhagen et al. 2004).

Resistance to E. carotovora subsp. carotovora, in terms of both plant survival and defense gene expression, mediated by Streptomyces spp. EN27 and EN28 and N. albus EN46, appears to occur via the JA/ET pathway, whereas Micromonospora EN43-mediated resistance correlates with increased expression of genes in both the JA/ET and SAR pathways. The SAR and ISR pathways have been shown to be additive by van Wees and associates (2000), who demonstrated, in Arabidopsis, that the SAR and ISR pathways singly resulted in 40 to $60 \%$ reduction, respectively, in disease symptoms of $P$. syringae pv. tomato. When ISR and SAR genes were expressed simultaneously, disease reduction was enhanced up to $80 \%$. Therefore, because Micromonospora sp. strain EN43 has the ability to activate both the SAR and JA/ET pathways, it may prove to be a broad-ranging biocontrol agent.

Induced resistance to the soilborne fungus $F$. oxysporum, mediated by the endophytic actinobacteria, occurred primarily by the SAR pathway. The $P R-1$ and $P R-5$ genes both were expressed at a higher level in the plants inoculated with the endophytic actinobacteria. Previously, it has been shown that infection of Arabidopsis with $F$. oxysporum induces the defense-related gene, thionin (Thi2.1), and overexpression of this gene results in resistance (Epple et al. 1997). Berrocal-Lobo and Molina (2004) found induction of the $P R-1$ transcript 4 days after infection and, by 8 days, both $P R-1$ and $P D F 1.2$ were induced, demonstrating activation of both the SAR and JA/ET pathways by $F$. oxysporum. The endophytic actinobacteria, though, can upregulate both the SAR pathway and JA/ET pathway defense genes and, when both pathways are in opera-

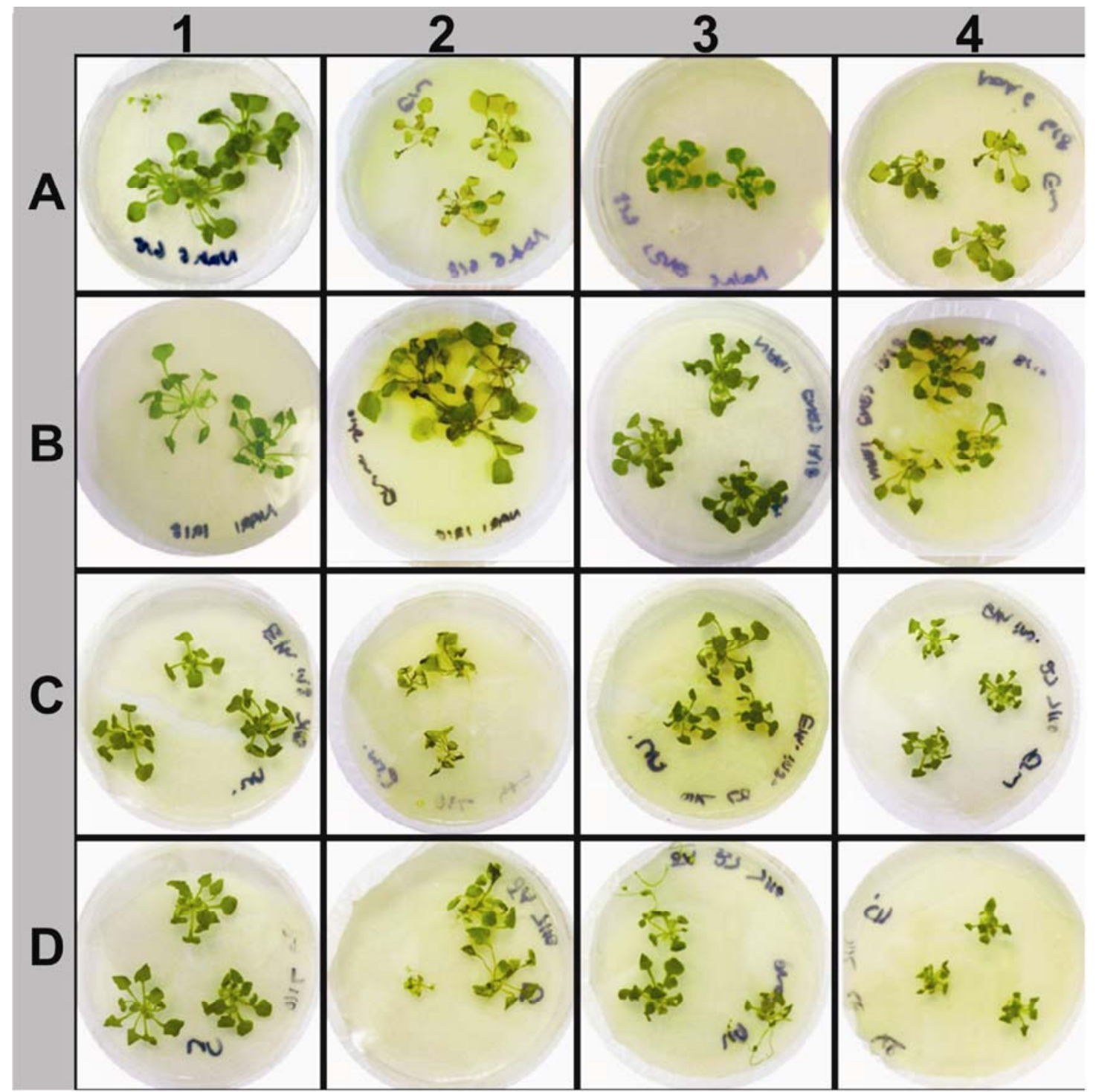

Fig. 5. Defense-compromised Arabidopsis thaliana plants. A, NahG mutants; B, nprl mutants; C, etr1-3 mutants; D, jarl-1 mutants; column 1, 7-week-old untreated plants; column 2, 7-week-old plants 3 days after inoculation with Erwinia carotovora subsp. carotovora at $3 \times 10^{8} \mathrm{CFU} \mathrm{ml}^{-1}$; column 3, 7-weekold plants grown from seed inoculated with Streptomyces sp. strain EN27 at $1 \times 10^{8} \mathrm{CFU} \mathrm{m}^{-1}$; column 4, 7-week-old plants grown from seed inoculated with Streptomyces sp. strain EN27 at $1 \times 10^{8} \mathrm{CFU} \mathrm{ml}^{-1}$ and 3 days after inoculation with E. carotovora subsp. carotovora at $3 \times 10^{8} \mathrm{CFU} \mathrm{ml}{ }^{-1}$. 
tion, a stronger protection may be manifested. In contrast, defense responses by $P$. fluorescens WC417r or LSW17S and Bacillus spp. is SA independent and associated with JA and ET (Kloepper et al. 2004; Pieterse et al. 1996, 1998).

The defense pathways activated by the endophytic actinobacterium Streptomyces sp. strain EN27 were further dissected using Arabidopsis defense-compromised mutants. In this study, it was found that the Streptomyces sp. strain EN27-mediated resistance to E. carotovora subsp. carotovora required SA because the NahG mutants were unable to mount a defense response upon infection. This response is opposite to that obtained with $P$. fluorescens LSW17S, which was able to reduce pathogen proliferation with this NahG mutant (Ahn et al. 2007). $N a h G$ mutants are unable to accumulate SA, because the $N a h G$ transgene salicylate hydroxylase converts SA to the inactive form catechol and, therefore, is unable to induce $P R-1$ (Lawton et al. 1995). However, because NahG mutants have manifested pleiotropic effects, these results need to be con- firmed using SA-deficient sid2 mutants (Heck et al. 2003; van Wees and Glazebrook 2003).

Although SA is essential for Streptomyces sp. strain EN27mediated resistance to the pathogen, it occurred via an NPR1independent pathway. Streptomyces sp. strain EN27-treated npr 1-1 mutants infected with E. carotovora subsp. carotovora demonstrated PR-1,PDF1.2, and $\mathrm{Hel}$ induction correlating with resistance because the plants showed little symptom of disease, indicating that an NPR1-independent pathway must have been functioning. Shah and associates (1999) identified the dominant mutation ssil (suppressor of SA immunity), where $P R-1, P R-2$, and $P R-5$ were expressed constitutively and the requirement for NPR1 was bypassed. SSI1 is thought to function as a switch, modulating cross-talk between the SAand JA/ET-mediated defense pathways. Evidence for SA-dependent but NPR1-independent pathways for regulation of $P R$ 1 gene expression and resistance to bacterial pathogens has been reported previously (Bowling et al. 1997; Clarke et al.

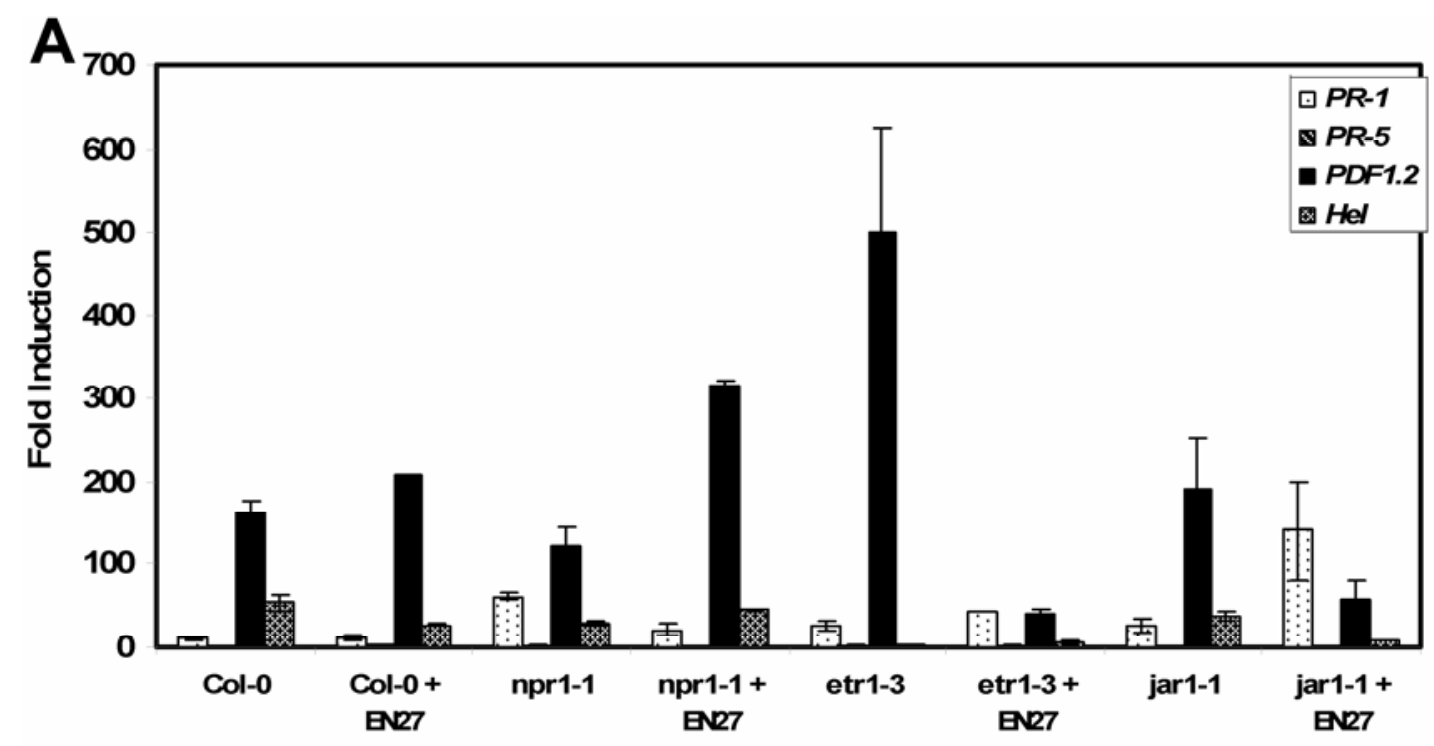

Arabidopsis Mutant and Treatment

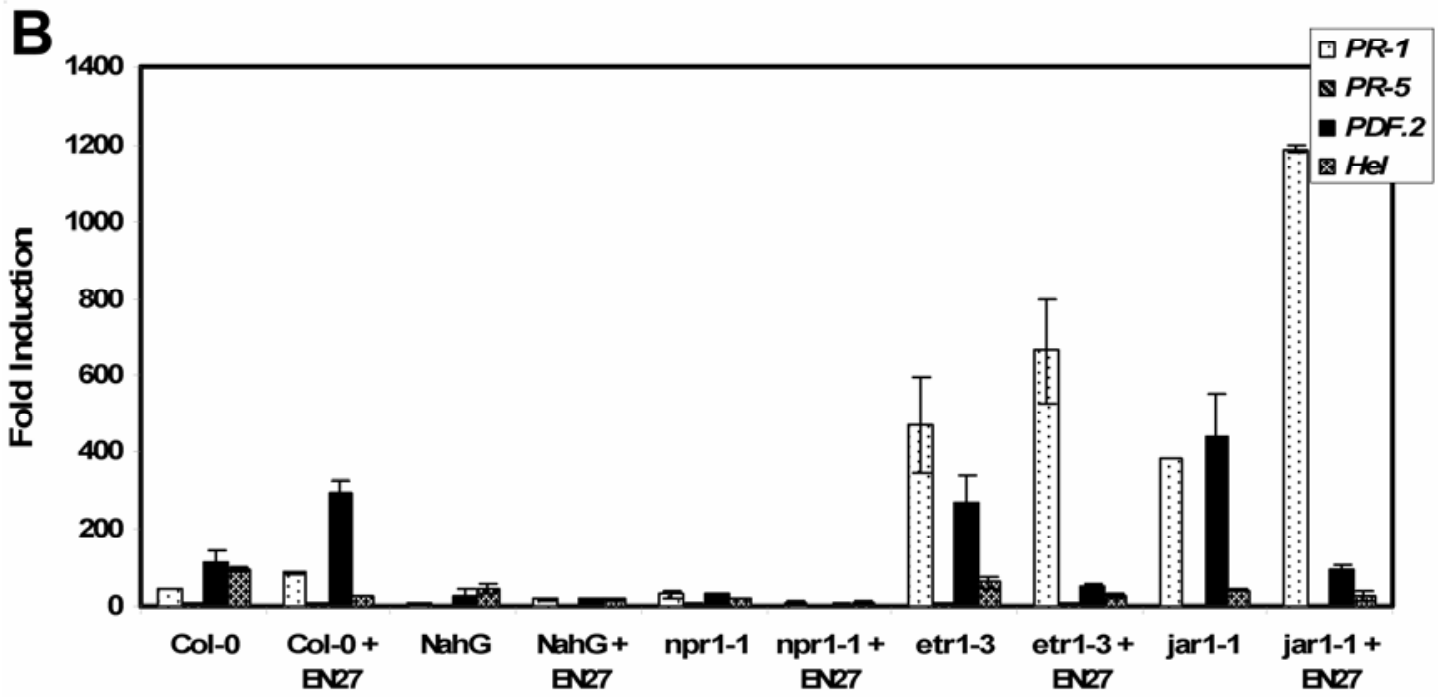

Arabidopsis Mutant and Treatment

Fig. 6. Induction of systemic acquired resistance ( $P R-1$ and $P R-5)$ and jasmonic acid/ethylene pathway genes ( $P D F 1.2$ and $H e l) 3$ days after challenge with A, Erwinia carotovora subsp. carotovora or B, Fusarium oxysporum. Wild-type (Col-0), and defense-compromised plants NahG, npr1-1, etrl-3, and jarl of Arabidopsis were either untreated or treated at sowing with Streptomyces sp. strain EN27 (+EN27). 
1998; Devadas et al. 2002; Rairdan and Delaney 2002; Rate et al. 1999) and we conclude that a similar mode of resistance is operational with the endophytic actinobacteria.

Norman-Setterblad and associates (2000) found that resistance to E. carotovora subsp. carotovora occurred via two types of defense pathways, one JA-dependent and inhibited by SA and the other ET- and JA-dependent but potentiated by SA. Infection with E. carotovora subsp. carotovora was shown to trigger the JA/ET pathway in wild-type (Col-0) plants and the PDF 1.2 transcript was further upregulated upon Streptomyces sp. strain EN27 treatment. Therefore, it was anticipated that resistance mediated by Streptomyces sp. strain EN27 would be abolished in plants defective in JA and ET signaling. However, analysis of the gene expression in E. carotovora subsp. carotovora-infected jarl-1 and etrl-3 plants revealed that PDF1.2 still could be expressed, similar to the findings of Penninckx and associates (1996) with the etrl-3 mutant upon infection with Alternaria brassicicola. When the JA and ET mutants were treated with Streptomyces sp. strain EN27, resistance to E. carotovora subsp. carotovora was observed but the expression of PDFl.2 and $\mathrm{Hel}$ were significantly reduced. Instead, the SAR pathway gene $P R-1$ expression was increased compared with the untreated plants. It is possible that JA/ET mutants inoculated with Streptomyces sp. strain EN27 are able to detect that the JA/ET pathway is defective and develop resistance by triggering the SAR pathway. Our findings suggest that resistance to E. carotovora subsp. carotovora mediated by Streptomyces sp. strain EN27 occurs via an NPR1-independent pathway that requires SA, but not JA and ET.

Infection of the two SAR mutants, NahG and $n p r l$, with the hemibiotroph $F$. oxysporum revealed minimal SAR and JA/ET gene expression, indicating that SA and the NPR1 protein are essential for the development of a resistant phenotype. Analysis of the JA- and ET-insensitive mutants infected with $F$. oxysporum revealed that JA/ET signaling is not correlated with the ability to mount a defense response. In fact, when the JA/ET mutants were inoculated with Streptomyces sp. strain EN27 and infected with either pathogen, there was a clear shift to the SAR pathway and $P R-1$ expression was significantly enhanced. It appears that treatment with Streptomyces sp. strain EN27 enabled detection of the defective JA/ET pathway and switching to the functioning SAR pathway. We conclude that, in contrast to the bacterial pathogen, resistance to the fungus $F$. oxysporum, mediated by Streptomyces sp. strain EN27, occurred via an NPR1-dependent pathway but also required SA and was JA/ET independent.

It is recognized that there is not always a strong correlation between expression of defense-related genes and disease resistance in ISR (Ahn et al. 2007), and that other defense-related mechanisms such as callose deposition, accumulation of active oxygen species, and papillae formation also may be activated (Verhagen et al. 2004; Wang et al. 2005). Of interest, the endophytic streptomycete used in this study is able to offer protection to the nprl, etrl-3, and jarl-1 plants but not NahG, whereas $P$. fluorescens LSW17S was able to protect only $N a h G$ plants (Ahn et al. 2007). Subsequently, priming with $P$. fluorescens LSW17S was able to elicit expression of PDF1.2 in $N a h G$ plants only, whereas this gene was expressed in all the other mutants primed with Streptomyces sp. strain EN27.

Inoculation of wild-type Arabidopsis thaliana with selected strains of endophytic actinobacteria was able to prime the defense pathways by inducing low-level expression of SAR and JA/ET genes. Upon pathogen infection, the defense genes are strongly upregulated and the endophyte-treated plants were demonstrated to have a higher abundance of the defense gene transcripts. This ability to prime the plant for an augmented response to pathogen attack is expected to confer a fitness advantage (van Hulten et al. 2006) to the endophyte-treated plants. This capacity to induce disease resistance in a versatile manner is expected to work in concert with their proven antibiotic effects and their colonization efficiency, making these endophytes excellent candidates for effective biocontrol agents.

\section{MATERIALS AND METHODS}

\section{Endophytic actinobacteria cultures.}

The endophytic actinobacteria cultures EN27 (Streptomyces sp. strain AY148075), EN28 (Streptomyces sp. strain AY148076), EN43 (Micromonospora sp. strain AY291589), and EN46 ( $N$. albus AY148081) were maintained on half-strength potato dextrose ( $1 / 2$ PDA) agar and EN2 (Microbispora $\mathrm{sp}$. strain AY148073) on oatmeal agar. All the actinobacteria used in this study were isolated previously from surface-sterilized healthy wheat roots, as described previously (Coombs and Franco 2003b).

\section{Plant pathogens.}

E. carotovora subsp. carotovora, originally isolated from leek, was grown on $1 / 2$ PDA at $27^{\circ} \mathrm{C}$ for 3 to 4 days. A suspension of the bacterial cells was prepared in sterile saline $(0.9 \%$ $\mathrm{NaCl}$ ) to a final concentration of $1 \times 10^{8} \mathrm{CFU} \mathrm{\textrm {ml } ^ { - 1 }}$. F . oxysporum, originally isolated from cucumber, was maintained on $1 / 2$ PDA. A plug of the culture was used to inoculate $50 \mathrm{ml}$ of Sabouraud broth and incubated at $27^{\circ} \mathrm{C}$ for 3 days at $150 \mathrm{rpm}$.

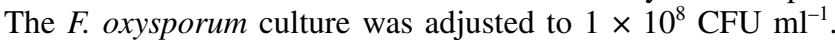
The E. carotovora subsp. carotovora and F. oxysporum cultures were kindly provided by the Horticultural Pathology and Nematology Group at the South Australian Research and Development Institute, Adelaide, Australia.

\section{Plant cultivation.}

Arabidopsis thaliana (ecotype Columbia-0 and mutants nprl-1, jarl-1, etr1-3, and NahG) plants were grown on halfstrength Murashige and Skoog $(1 / 2$ MS) salt medium (SigmaAldrich, Sydney, Australia), with 0.8\% Bacto-agar (Bacto Laboratories, Liverpool, Australia) as the gelling agent when the plants were grown on plates with a horizontal orientation or $0.8 \%$ phytagel agar (Sigma-Aldrich) if grown on plates with a

Table 2. Amplification efficiency and sequence of primers used for quantitative polymerase chain reaction

\begin{tabular}{|c|c|c|c|}
\hline Target gene & Accession no. & Primer sequence & Amplification efficiency ${ }^{\mathrm{a}}$ \\
\hline \multirow[t]{2}{*}{$\mathrm{Hel}$} & NM_111344 & Forward: 5' CAA GTG TTT AAG GGT GAA GA 3' & \\
\hline & & Reverse: 5' CGG TGT CTA TTT GAT TGA AC 3' & 1.89 \\
\hline \multirow[t]{2}{*}{ PDF1.2 } & AY133787 & Forward: 5' CTG CTC TTG TTC TCT TTG CT 3' & \\
\hline & & Reverse: 5' GTG TGC TGG GAA GAC ATA 3' & 1.78 \\
\hline \multirow{2}{*}{$P R-1$} & AY117187 & Forward: 5' GCC TTA CGG GGA AAA CTT A 3' & \\
\hline & & Reverse: 5' CTT TGG CAC ATC CGA GTC T 3' & 1.64 \\
\hline \multirow[t]{2}{*}{$P R-5$} & AY059114 & Forward: 5' CGG AAA CGG TAG ATG TGT AAC $3^{\prime}$ & \\
\hline & & Reverse: 5' GTT GAG GTC AGA GAC ACA GCC 3' & 1.69 \\
\hline
\end{tabular}

\footnotetext{
${ }^{\text {a }}$ The amplification efficiency for Actin is 1.61 .
} 
vertical orientation. Growth on agar was selected because sterile conditions can be maintained which enabled the effects from only the experimental microorganism, in this case actinobacteria, to be studied and interference from contamination microorganisms to be ruled out. This is especially critical for the study of ISR. The plants appeared healthy on agar and did not represent a stressed condition. In all cases, untreated plants were used as controls to provide a direct comparison of expression levels. Seed were surfaced sterilized by immersing in $70 \%$ (vol/vol) ethanol for $1 \mathrm{~min}$ followed by $1 \mathrm{ml}$ of $12 \%$ sodium hypochlorite (as fresh Domestos bleach) for $10 \mathrm{~min}$. The seed then were rinsed twice in sterile $2 \%$ (wt/vol) sodium thiosulfate to remove the residual chlorine (Miche and Balandreau 2001) and a minimum of 5 washes with sterile $\mathrm{H}_{2} \mathrm{O}$ to remove all traces of sodium hypochlorite. Seed were placed onto $1 / 2$ MS salt medium and the plates were sealed with micropore tape and placed at $4^{\circ} \mathrm{C}$ overnight to achieve even germination. Plants then were transferred to a light box with a 9-h light cycle, 2,000 lux, with the temperature of $20 \pm 4^{\circ} \mathrm{C}$. Arabidopsis mutant seed nprl-1 (CS3726) (Cao et al. 1994), jarl-1 (Salk_011510) (Alonso et al. 2003), and etrl-3 (CS3070) (Guzman and Ecker 1990) were obtained from the Arabidopsis Biological Resource Centre. The NahG (Lawton et al. 1995) B15 seed were kindly provided by Novartis, Research Triangle Park, North Carolina, U.S.A.

\section{Chemical treatment and \\ endophytic actinobacterial inoculation of plants.}

Six- to eight-week-old Col-0, nprl-1, jarl-1, etrl-3, and $N a h G$ plants were sprayed with $5 \mathrm{mM} \mathrm{SA}, 50 \mu \mathrm{M}$ MeJA, or $0.01 \%(\mathrm{wt} / \mathrm{vol}) \mathrm{ACC}$ and whole plants were harvested at 6 and 24 h. Surface-sterilized Col-0 seed were inoculated with endophytic actinobacterial suspensions containing $10^{8}$ spores, or $\mathrm{H}_{2} \mathrm{O}$ for control plants, and left to dry in the laminar flow cabinet. The seed was inoculated to ensure that the endophyte had maximum opportunity to colonize the plant as the seed germinated, as demonstrated in previous studies by Coombs and Franco (2003a).

\section{Inoculation of Arabidopsis (Col-0) with endophytic actinobacteria culture filtrates.}

Endophytic actinobacterial culture filtrates were prepared by inoculating $50 \mathrm{ml}$ of inoculum medium (glucose at $15 \mathrm{~g} \mathrm{liter}^{-1}$, soybean meal at $15 \mathrm{~g} \mathrm{liter}^{-1}$, corn steep liquor at $5 \mathrm{~g} \mathrm{liter}^{-1}$, $\mathrm{NaCl}$ at $5 \mathrm{~g} \mathrm{liter}^{-1}$, and $\mathrm{CaCO}_{3}$ at $2 \mathrm{~g} \mathrm{liter}^{-1} ; \mathrm{pH}$ 7.2) with a loop of the actinobacteria spores. The inoculum medium was grown at $27^{\circ} \mathrm{C}$ for 3 days with shaking at $150 \mathrm{rpm}$. The wellgrown inoculum culture $(5 \%, \mathrm{vol} / \mathrm{vol})$ then was used to inoculate 250-ml Erlenmeyer flasks containing $50 \mathrm{ml}$ of FLO26 medium (glucose at $20 \mathrm{~g} \mathrm{liter}^{-1}$, soybean meal at $10 \mathrm{~g} \mathrm{liter}^{-1}$, $\mathrm{CaCO}_{3}$ at $4 \mathrm{~g} \mathrm{liter}^{-1}$, and $\mathrm{CoCl}_{2} \cdot 6 \mathrm{H}_{2} \mathrm{O}$ at $1 \mathrm{mg} \mathrm{liter}^{-1} ; \mathrm{pH} 7.2$ ) or FL031 medium (glycerol at $15 \mathrm{~g} \mathrm{liter}^{-1}$, glucose at $5 \mathrm{~g} \mathrm{liter}^{-}$ 1, Pharmamedia at $20 \mathrm{~g} \mathrm{liter}^{-1}$, yeast extract at $5 \mathrm{~g} \mathrm{liter}^{-1}$, $\mathrm{KH}_{2} \mathrm{PO}_{4}$ at $1 \mathrm{~g} \mathrm{liter}^{-1}, \mathrm{MgSO}_{4} \cdot 7 \mathrm{H}_{2} \mathrm{O}$ at $0.5 \mathrm{~g} \mathrm{liter}^{-1}, \mathrm{CaCO}_{3}$ at $2 \mathrm{~g} \mathrm{liter}^{-1}, \mathrm{CuSO}_{4} \cdot 5 \mathrm{H}_{2} \mathrm{O}$ at $7 \mathrm{mg} \mathrm{liter}^{-1}, \mathrm{FeSO}_{4} \cdot 7 \mathrm{H}_{2} \mathrm{O}$ at $1 \mathrm{mg}$ liter ${ }^{-1}, \mathrm{MnCl}_{2} \cdot 4 \mathrm{H}_{2} \mathrm{O}$ at $8 \mathrm{mg} \mathrm{liter}{ }^{-1}$, and $\mathrm{ZnSO}_{4} \cdot 7 \mathrm{H}_{2} \mathrm{O}$ at 2 mg liter ${ }^{-1}$; $\mathrm{pH}$ 7.2). After 8 days at $27^{\circ} \mathrm{C}$ with shaking at 150 $\mathrm{rpm}$, the cultures were transferred to sterile 50 -ml falcon tubes and centrifuged at $4,000 \times g$ for $5 \mathrm{~min}$. The culture broth was removed and filtered through a $0.8-\mu \mathrm{m}$ Millipore filter to remove bacterial cells. The filtrate was used to treat the roots of 6- to 8-week-old Col-0 plants.

\section{Arabidopsis pathogen challenge.}

Six- to eight-week-old endophyte-inoculated and untreated Col-0, npr1-1, jarl-1, etr1-3, and NahG plants were challenged separately with $F$. oxysporum and E. carotovora subsp. caroto- vora. $F$. oxysporum, as a $1 \times 10^{8} \mathrm{CFU} \mathrm{m}^{-1}$ suspension, was applied directly to the roots of the plants. E. carotovora subsp. carotovora, as a $1 \times 10^{8} \mathrm{CFU} \mathrm{ml}^{-1}$ suspension, was applied by pressure infiltration to all of the leaves using a needleless syringe. Sterile saline was applied to control plants. The whole plants were harvested 3 days postchallenge, which was chosen on the basis of a time course of the disease progression and expression of defense genes for E. carotovora subsp. carotovora (Aguilar et al. 2002) and F. oxysporum (Epple et al. 1995). Plant material was harvested by carefully removing the plants from the medium and immediately freezing in liquid nitrogen.

\section{Analysis of gene expression by QPCR.}

Total RNA was extracted from 100 to $200 \mathrm{mg}$ of snap-frozen Arabidopsis tissue with Trizol (Invitrogen, Sydney, Australia). Contaminating DNA was removed from RNA preparations using RQ-1 RNase-free DNase-1 (Promega, Annandale, Australia) or Turbo DNA-free (Ambion, Cambridge, U.K.). RNA was converted to cDNA using Omniscript reverse transcriptase (Qiagen, Valencia, CA, U.S.A.) with $1 \mu \mathrm{g}$ of RNA pooled from nine plants and Oligo dT primers $\left(50 \mathrm{ng} \mu \mathrm{l}^{-1}\right)$. The cDNA was diluted 1:4 with sterile $\mathrm{H}_{2} \mathrm{O}$ and $2 \mu \mathrm{l}$ of cDNA used per 10- $\mu$ l QPCR reaction. The housekeeping gene Actin was used to normalize the experimental genes. Primers designed by An and associates (1996) and Charrier and associates (2002) were used to amplify Actin2 and Actin 8 genes simultaneously. QPCR primers for the Hel, PDF 1.2, PR-1, and PR-5 genes were prepared by Geneworks (Adelaide, Australia) and the primer sequences designed in this study are presented in Table 2. PCR products using the primers were sequenced to confirm correct amplification of the target gene. For all samples, duplicate reactions with a final volume of $10 \mu \mathrm{l}$ consisted of: $10 \mathrm{ng}$ of each primer, $200 \mu \mathrm{M}$ dNTPs, $1.5 \mathrm{mM} \mathrm{MgCl}$, 0.4× SYBR Green-1 (Molecular Probes, Eugene, OR, U.S.A), 1× Qiagen PCR Buffer, 0.25 units of Hot Star Taq (Qiagen), and $2 \mu \mathrm{l}$ of cDNA per reaction. Amplification of Actin, Hel, $P D F 1.2$, and $P R-5$ products were performed in the Rotorgene 2000 (Corbett Research, Sydney, Australia) with the following thermal cycle profile: $95^{\circ} \mathrm{C}$ for $15 \mathrm{~min}$ followed by 35 cycles of $94^{\circ} \mathrm{C}$ for $20 \mathrm{~s}, 54^{\circ} \mathrm{C}$ for $20 \mathrm{~s}$, and $72^{\circ} \mathrm{C}$ for $20 \mathrm{~s}$. For amplification of $P R-1$, the following thermal cycle profile was used: $95^{\circ} \mathrm{C}$ for $15 \mathrm{~min}$ followed by 40 cycles of $94^{\circ} \mathrm{C}$ for $20 \mathrm{~s}, 56^{\circ} \mathrm{C}$ for $20 \mathrm{~s}$, and $72^{\circ} \mathrm{C}$ for $20 \mathrm{~s}$. Products then were melted by heating from 65 to $92^{\circ} \mathrm{C}$ over $5 \mathrm{~min}$. Data was acquired on the SYBR-green channel with the gain set at 7 and, for both quantitation and melt analysis, a "light" digital filter was utilized to smooth raw fluorescence readings. Melt-curve analysis was carried out with the $\mathrm{dF} / \mathrm{dT}$ threshold set above the fluorescence background at a value of 1 for detection of single melt products. The amplification efficiency of each primer set was determined using serial dilutions of purified PCR products. PCR products for each gene were purified with the UltraClean PCR Purification kit (MoBio, Carlsbad, CA, U.S.A.). Serial 10-fold dilutions of the purified PCR products were made and $2 \mu \mathrm{l}$ used as the template in the QPCR. A standard curve was generated using the Rotorgene 2000 software based on the leastsquares linear regression method with the cycle threshold $(\mathrm{Ct})$ values plotted against the $\log _{10}$ (copy number). The slope of this standard curve was used to determine amplification efficiency $(E)$ using the calculation $E=10(-1 /$ slope $)$. Standard deviations and coefficient of variance were determined for each run and found to be less than $2 \%$ intra-run and 1 to $10 \%$ interrun.

\section{Relative quantification of gene expression (QPCR).}

$\mathrm{Ct}$ values were obtained from raw fluorescence data using quantitation analysis options in the Rotorgene 2000 software 
(Corbett Research, Sydney, Australia). The fluorescence threshold was set at 0.03 , dynamic tube normalization was applied to correct for background fluorescence in raw data, and the first five cycles were ignored. The $\mathrm{Ct}$ values were used to calculate the fold induction of the target gene in each sample. The comparative $\mathrm{Ct}$ or $\Delta \Delta-\mathrm{Ct}$ equation developed by Pfaffl (2001) was used to calculate relative gene expression, normalized against the expression of the housekeeping gene transcript Actin (Livak and Schmittgen 2001). The reverse-transcription PCR results are presented as means of duplicate QPCR where the RNA was pooled from nine plants. Two independent experiments were carried out to validate the results.

\section{ACKNOWLEDGMENTS}

This work was supported by the Australian Grain Research and Development Corporation.

\section{LITERATURE CITED}

Abeles, F. B., Morgan, P. W., and Saltveit, M. E., Jr. 1992. Ethylene in Plant Biology. Academic Press Inc., San Diego, CA, U.S.A.

Aguilar, I., Alamillo, J. M., Garcia-Olmedo, F., and Rodriguez-Palenzuela, P. 2002. Natural variability in the Arabidopsis response to infection with Erwinia carotovora subsp. carotovora. Planta 215:205-209.

Ahn, I.-P., Lee, S.-W., and Suh, S.-C. 2003. Rhizobacteria-induced priming in Arabidopsis is dependent on ethylene, jasmonic acid and NPRI. Mol. Plant-Microbe Interact. 20:759-768

Alonso, J. M., Stepanova, A. N., Leisse, T. J., Kim, C. J., Chen, H., Shinn, P., Stevenson, D. K., Zimmerman, J., Barajas, P., Cheuk, R., Gadrinab, C., Heller, C., Jeske, A., Koesema, E., Meyers, C. C., Parker, H., Prednis, L., Ansari, Y., Choy, N., Deen, H., Geralt, M., Hazari, N., Hom, E., Karnes, M., Mulholland, C., Ndubaku, R., Schmidt, I., Guzman, P., Aguilar-Henonin, L., Schmid, M., Weigel, D., Carter, D. E., Marchand, T., Risseeuw, E., Brogden, D., Zeko, A., Crosby, W.L., Berry, C. C., and Ecker, J. R. 2003. Genome-wide insertional mutagenesis of Arabidopsis thaliana. Science 203:653-657.

An, Y., McDowell, J. M., Huang, S., McKinney, E. C., Chambliss, S., and Meagher, R. B. 1996. Strong, constitutive expression of the Arabidopsis ACT2/ACT8 actin subclass in vegetative tissues. Plant J. 10:107-121.

Berrocal-Lobo, M., and Molina, A. 2004. Ethylene response factor 1 mediates Arabidopsis resistance to the soilborne fungus Fusarium oxysporum. Mol. Plant-Microbe Interact. 17:763-770.

Bowling, S. A., Clarke, J. D., Liu, Y., Klessig, D. F., and Dong, X. 1997. The CPR5 mutant of Arabidopsis expresses both NPR1-dependent and NPR1-independent resistance. Plant Cell 9:1573-1584.

Cao H., Bowling S. A., Gordon, A. S., and Dong, X. N. 1994. Characterization of an Arabidopsis mutant that is nonresponsive to inducers of systemic acquired resistance. Plant Cell 6:1583-1592.

Charrier, B., Champion, A., Henry, Y., and Kreis, M. 2002. Expression profiling of the whole Arabidopsis shaggy-like kinase multigene family by real-time reverse transcriptase-polymerase chain reaction. Plant Physiol. 130:577-590.

Clarke, J. D., Liu, Y., Klessig, D. F., and Dong, X. 1998. Uncoupling PR gene expression from NPR1 and bacterial resistance: characterization of the dominant Arabidopsis cpr6-1 mutant. Plant Cell 10:557-569.

Conrath, U., Pieterse, C. M., and Mauch-Mani, B. 2002. Priming in plantpathogen interactions. Trends Plant Sci. 7:210-216.

Coombs, J. T. 2002. The isolation and characterisation of endophytic actinomycetes from wheat (Triticum aestivum). Ph.D. thesis, Department of Medical Biotechnology, Flinders University, Adelaide, Australia.

Coombs, J. T., and Franco, C. M. M. 2003a. Visualization of an endophytic Streptomyces species in wheat seed. Appl. Environ. Microbiol. 69:42604262.

Coombs, J. T., and Franco, C. M. M. 2003b. Isolation and identification of actinobacteria isolated from surface-sterilized wheat roots. Appl. Environ. Microbiol. 69:5603-5608.

Coombs, J. T., Michelsen, P. P., and Franco, C. M. M. 2003. Evaluation of endophytic actinobacteria as antagonists of Gaeumannomyces graminis var. tritici in wheat. Biol. Control. 29:359-366.

Creelman, R. A., and Mullet, J. E. 1997. Biosynthesis and action of jasmonates in plants. Annu. Rev. Plant Physiol. Plant Mol. Biol. 48:355-381.

Devadas, S. K., Enyedi, A., and Raina, R. 2002. The Arabidopsis hrl1 mutation reveals novel overlapping roles for salicylic acid, jasmonic acid and ethylene signaling in cell death and defence against pathogens. Plant J. 30:467-480.
Dong, X., and Durrant, W. E. 2004. Systemic acquired resistance. Annu. Rev. Phytopathol. 42:185-209.

Duijff, B. J., Alabouvette, C., and Lemanceau, P. 1996. Involvement of induced systemic resistance in the control of Fusarium wilt of tomato by Fusarium oxysporum strain FO47 and Pseudomonas fluorescens strain WCS417r. Int. Organ. Biol. Integrated Control Noxious Anim. Plants/West Palaearctic Reg. Sec. Bull. 19:120-124.

Ellis, C., and Turner, J. G. 2001. The Arabidopsis mutant cev1 has constitutively active jasmonate and ethylene signal pathways and enhanced resistance to pathogens. Plant Cell 13:1025-1033.

Epple, P., Apel, K., and Bohlmann, H. 1995. An Arabidopsis thaliana thionin gene is inducible via a signal transduction pathway different from that for pathogenesis-related proteins. Plant Physiol. 109:813-820.

Epple, P., Apel, K., and Bohlmannl, H. 1997. Overexpression of an endogenous thionin enhances resistance of Arabidopsis against Fusarium oxysporum. Plant Cell 9:509-520.

Glazebrook, J. 2005. Contrasting mechanisms of defense against biotrophic and necrotrophic pathogens. Annu. Rev. Phytopathol. 43:205-227.

Guzman P. E., and Ecker J. R. 1990. Exploiting the triple response of Arabidopsis to identify ethylene-related mutants. Plant Cell 2:513-523.

Hammerschmidt, R. 1999. Induced disease resistance: how do induced plants stop pathogens? Physiol. Mol. Plant Pathol. 55:77-84.

Heck, S., Grau, T., Buchala, A., Metraux, J. P., and Nawrath, C. 2003. Genetic evidence that expression of NahG modifies defence pathways independent of salicylic acid biosynthesis in the Arabidopsis-Pseudomonas syringae pv. tomato interaction. Plant J. 36:342-352.

Hopwood, D. A. 2003. The Streptomyces genome-be prepared! Nat. Biotechnol. 21:505-506.

Kloepper, J. W., Ryu, C.-M., and Zhang, S. 2004. Induced systemic resistance and promotion of plant growth by Bacillus spp. Phytopathology 94:1259-1266

Lawton, K., Weymann, K., Friedrich, L., Vernooij, B., Uknes, S., and Ryals, J. 1995. Systemic acquired resistance in Arabidopsis requires salicylic acid but not ethylene. Mol. Plant-Microbe Interact. 8:863-870.

Leeman, M., van Pelt, J. A., den Ouden, F. M., Heinsbroek, M., Bakker, P A. H. M., and Schippers, B. 1995. Induction of systemic resistance by Pseudomonas fluorescens in radish cultivars differing in susceptibility to Fusarium wilt, using a novel bioassay. Eur. J. Plant Pathol. 101:655664.

Livak, K. J., and Schmittgen, T. D. 2001. Analysis of relative gene expression data using real-time quantitative PCR and the $2^{-\Delta \Delta C T}$ method. Methods 25:402-408.

Maldonado, A. M., Doerner, P., Dixon, R. A., Lamb, C. J., and Cameron, R. K. 2002. A putative lipid transfer protein involved in systemic resistance signaling in Arabidopsis. Nature 419:399-403.

Miche, L., and Balandreau, J. 2001. Effects of rice seed surface sterilization with hypochlorite on inoculated Burkholderia vietnamiensis. Appl. Environ. Microbiol. 67:3046-3052.

Nolan, R. D., and Cross, T. 1988. Isolation and screening of actinomycetes. In: Actinomycetes in Biotechnology. M. Goodfellow, S. T. Williams, and M. Modarski, eds. Academic Press, London.

Norman, C., Vidal, S., and Palva, E. T. 1999. Oligogalacturonide-mediated induction of a gene involved in jasmonic acid synthesis in response to the cell-wall-degrading enzymes of the plant pathogen Erwinia carotovora. Mol. Plant-Microbe Interact. 12:640-644.

Norman-Setterblad, C., Vidal, S., and Palva, E. T. 2000. Interacting signal pathways control defense gene expression in Arabidopsis in response to cell wall-degrading enzymes from Erwinia carotovora. Mol. PlantMicrobe Interact. 13:430-438.

Penninckx, I. A., Eggermont, K., Terras, F. R., Thomma, B. P., De Samblanx, G. W., Buchala, A., Metraux, J. P., Manners, J. M., and Broekaert, W. F. 1996. Pathogen-induced systemic activation of a plant defensin gene in Arabidopsis follows a salicylic acid-independent pathway. Plant Cell 8:2309-2323.

Pfaffl, M. W. 2001. A new mathematical model for relative quantification in real-time RT-PCR. Nucleic Acids Res. 29:e45.

Pieterse, C. M., van Wees, S. C., Hoffland, E., van Pelt, J. A., and van Loon, L. C. 1996. Systemic resistance in Arabidopsis induced by biocontrol bacteria is independent of salicylic acid accumulation and pathogenesis-related gene expression. Plant Cell 8:1225-1237.

Pieterse, C. M., van Wees, S. C., van Pelt, J. A., Knoester, M., Laan, R., Gerrits, H., Weisbeek, P. J., and van Loon, L. C. 1998. A novel signaling pathway controlling induced systemic resistance in Arabidopsis. Plant Cell 10:1571-1580.

Pieterse, C. M. J., van Wees, S. C. M., Ton, J., van Pelt, J. A., and van Loon, L. C. 2002. Signaling in rhizobacteria-induced systemic resistance in Arabidopsis thaliana. Plant Biol. 4:535-544.

Rairdan, G. J., and Delaney, T. P. 2002. Role of salicylic acid and NIM1/NPR1 in race-specific resistance in Arabidopsis. Genetics 161:803-811. 
Rate, D. N., Cuenca, J. V., Bowman, G. R., Guttman, D. S., and Greenberg, J. T. 1999. The gain-of-function Arabidopsis acd6 mutant reveals novel regulation and function of the salicylic acid signaling pathway in controlling cell death, defenses, and cell growth. Plant Cell 11:1695-1708.

Ryu, C., Farag, M. A., Hu, C., Reddy, M. S., Kloepper, J. W., and Pare, P. W. 2004. Bacterial volatiles induce systemic resistance in Arabidopsis. Plant Physiol. 134:1017-1026.

Shah, J., Kachroo, P., and Klessig, D. F. 1999. The Arabidopsis SSI1 mutation restores pathogenesis-related gene expression in NPR1 plants and renders defensin gene expression salicylic acid dependent. Plant Cell 11:191-206.

Thaler, J. S., Owen, B., and Higgins, V. J. 2004. The role of the jasmonate response in plant susceptibility to diverse pathogens with a range of lifestyles. Plant Physiol. 135:530-538.

Uknes, S., Mauch-Mani, B., Moyer, M., Potter, S., Williams, S., Dincher, S., Chandler, D., Slusarenko, A., Ward, E., and Ryals, J. 1992. Acquired resistance in Arabidopsis. Plant Cell 4:645-656.

van Hulten, M., Pelser, M., van Loon, L. C., Pieterse, C. M. J., and Ton, J. 2006. Costs and benefits for priming for defense in Arabidopsis. Proc. Natl. Acad. Sci. U.S.A. 103:5602-5607.

van Loon, L. C., and van Stein, E. A. 1999. The families of pathogenesisrelated proteins, their activities, and comparative analysis of PR-1 type proteins. Physiol. Mol. Plant Pathol. 55:85-97.

van Peer, R., Niemann, G. J., and Schippers, B. 1991. Induced resistance and phytoalexin accumulation in biological control of Fusarium wilt of car- nation by Pseudomonas sp. strain WCS417r. Phytopathology 81:728-734. van Wees, S. C., and Glazebrook, J. 2003. Loss of non-host resistance of Arabidopsis NahG to Pseudomonas syringae pv. phaseolicola is due to degradation products of salicylic acid. Plant J. 33:733-742.

van Wees, S. C., Luijendijk, M., Smoorenburg, I., van Loon, L. C., and Pieterse, C. M. 1999. Rhizobacteria-mediated induced systemic resistance (ISR) in Arabidopsis is not associated with a direct effect on expression of known defense-related genes but stimulates the expression of the jasmonate-inducible gene Atvsp upon challenge. Plant Mol. Biol. 41:537-549.

van Wees, S. C., de Swart, E. A., van Pelt, J. A., van Loon, L. C., and Pieterse, C. M. 2000. Enhancement of induced disease resistance by simultaneous activation of salicylate- and jasmonate-dependent defense pathways in Arabidopsis thaliana. Proc. Nat. Acad. Sci. U.S.A. 97:8711-8716.

Verhagen, B. W. M., Glazebrook, J., Zhu, T., Chang, H. S., van Loon, L. C., and Pieterse, C. M. 2004. The transcriptome of rhizobacteriainduced systemic resistance in Arabidopsis. Mol. Plant-Microbe Interact. 17:895-908.

Wang, K. L. C., Li, H., and Ecker, J. R. 2002. Ethylene biosynthesis and signaling networks. Plant Cell Suppl. 2002:S131-S151.

Wang, Y., Ohara, Y., Nakayshiki, H., Tosa, Y., and Mayama, S. 2005. Microarray analysis of the gene expression profile of the endophytic plant growth-promoting rhizobacteria, Pseudomonas fluorescens FPT9601T5 in Arabidopsis. Mol. Plant-Microbe Interact. 18:385-396. 